\title{
Curriculum review and reorientation experience
}

\author{
J M Green
}

\begin{abstract}
OPSOMMING
'n Gevallestudie word aangebied oor die herkonseptualisering van Huishoudkunde in 'n tersiêre omgewing. 'n Behoeftebepaling en navorsing is by wyse van onderhoude met potensiële werkgewers en vorige gegradueerdes uitgevoer om die toepaslike uitkomste van Huishoudkunde-opvoeding te kan bepaal. Die literatuur het bykomende aanmoediging gebied om op kleinsake-inisiatiewe, huishoudelike voedselsekuriteit en die bestuur van ontwikkelingsprojekte te konsentreer. Die proses het die gelyktydige beplanning van leerondervindings, vakmateriaal en hul organisasie geverg. Die aanbevelings verwys onder meer na die wyer en deurlopende betrokkenheid by die proses van alle belangstellende universiteitspersoneel, en beter opleiding en groter ondersteuning van akademici wat veranderings aan hulle kurrikula moet aanbring.
\end{abstract}

\section{Dr J M Green}

Community Resources

University of Natal

\section{INTRODUCTION}

In the current climate of curriculum change, it seems appropriate to reflect on a major undergraduate curriculum review. The experience could be useful in informing others who are involved in or about to embark on a similar process. The review conducted by the Department of Home Economics at the University of Natal led to a major reconceptualisation of the Home Economics curriculum's content and ethos. An additional factor that influenced the changes was the apparent lack of success of the traditional curricula in addressing poverty issues. We needed to move away from the traditional modes of thinking in terms of which people were treated as objects to be developed, to be trained, to be educated (Hamdi, 1996).

What is a curriculum? It has been described as "what is taught, how it is taught, teachers' materials, students' material, educational experiences, all people's experiences" combined into a rational whole (Doll, 1989). The curriculum is the formal and informal content of learning. It is also the process by which learners gain knowledge and understanding, develop skills and alter attitudes, appreciations and values under the auspices of an educational institution. Reviewing or changing the curriculum is the replanning of the breadth or scope of knowledge. The improved, more effective outcomes bring about the required student learning in accordance with current expectations (Doll, 1989).

Tyler (1950) proposed a series of necessary steps for designing curricula. His rationale has been described as a linear model for curriculum planning that consisted of four elements: setting objectives, planning activities, organising activities and conducting evaluation. Objectives were to be selected on both philosophical and psychological grounds and they formed the basis for all subsequent planning processes. They were therefore critical to the whole process, yet difficult to state outside of mechanistic learning outcomes.

Subsequent use of Tyler's model has produced more specific stages in curriculum design:

- Investigate the need, based on educational, social and developmental criteria.

- State the major outcomes succinctly, indicating what needs to be done and how it would be achieved.

- Include the subject matter as part of the design (plan), and state how it would be organised for teaching and learning.

- Provide examples of learning experiences (activities), using the selected subject matter and the organisation of these experiences.

- Evaluate the programmes and projects in terms of objectives, implementation and institutionalisation (Levine, 1978; Doll, 1989).

The history of curriculum planning has shown that designers selected subject matter for its own sake and intrinsic worth rather than in the light of the problems of individuals and societies that needed solutions (Doll, 1989). Learners are not automatically able to apply the subject matter to related situations but need to practise how to do so (Hamdi, 1996). Boud and Feletti (1991) suggested an interesting problem-based approach to learning which directed the flow of information and the learning activities. This is the basis upon which our Home Economics curricula were redesigned.

Curriculum design should in practice include the motivation of staff and institutions to carry out the changes or innovations. A tentative set of principles was identified to illustrate this process:

- The staff would change enthusiastically if they 
felt the need for change themselves.

- The direction of improvement should be determined cooperatively.

- People should identify and examine centrally held values.

- The experience should be unthreatening with support from the leaders to overcome individual resistance to change.

- Problem-solving methods are suggested as the most successful - the personal linking of changes to current problem experiences.

- A climate of freedom to innovate, open channels of communication, and the absence of paternalism are needed.

- Encourage a self-driven process supported by inservice experiences and expertise (Doll, 1989).

The participants in the change process should include the academic staff, the university student administration, the public, the high schools feeding the programme, professional schools, employers, donors and other colleges (Levine, 1978). These stakeholders should provide continuous inputs for the changes to be implemented.

Elements of successful curriculum change are present when the environment is either unstable or particularly supportive. The character of the change should reflect the norms, values and traditions of the delivery institution. The way in which changes are introduced influences people's acceptance of change. Sufficient communication and publicity, leadership from administrators, wide-based support, rewards and resources provided, and appropriate forms of innovation management and organisation are essential to successful outcomes (Levine, 1978).

In the situation under consideration there were some deviations from this process, particularly in terms of progress and the time frame. The educational paradigm as previously applied in our Home Economics programme was reconceptualised in terms of the perceived needs of the changing South Africa.

\section{MOTIVATION FOR CHANGE}

The initial need for change was expressed by both students and staff. Some potential institutional rearrangements provided urgency to the process in terms of self-preservation. The planning was completed within a year. Interviews with students revealed that they were not enthusiastic about their studies nor about the potential job market. Contact with graduates revealed that they did not readily obtain jobs in the traditional sector of employment for home economists, and even then they seldom remained in the jobs for longer than 12 to 18 months. They complained of no status, poor pay, unchallenging work environments and little scope for promotion. In addition, with the high entry requirements for a science degree, we seemed to be attracting fewer and less capable students with passive views, limited creativity and lacking in innovative thinking.

Departmental academics strongly felt that there was some misfit between the course content, student expectations and the needs of KwaZulu-Natal in the area of home economics. Perceptions of home economics seemed synonymous with the low status roles that women play in the home. The historical perspective of developing housekeeping skills and good marriage roles was felt to be particularly irrelevant in the changing South African context but still prevalent in others' perceptions of home economics. Subject matter sometimes fell in the category of "nice to know" in the society of a bygone era. There was an image of strong technical skills rather than creative problem solving in important issues for families or resource-poor communities. This technical focus was also evident in some of the textbooks that are available. The paradigm at the University of Natal reflected the picture presented by Kwawu in 1993. Home economics needed to extend its systems of action to include both the interpretive and the critcal-emancipatory on a continuous basis (Murray, 1993). Questioning the importance and not just learning the method of activities should be integral to all subject matter.

These factors induced a strong motivation for reconceptualising of the subject matter and its delivery, thus increasing the relevance of academic offerings for the changing South Africa.

\section{ESSENTIAL OUTCOMES}

The next step was to survey the environment and trends evident in KwaZulu-Natal where graduate home economists would be expected to exhibit suitable skills. Potential employers, graduates and prospective students were approached. Literature on the economic base for the province showed that the dominant "home economics"-related industries were footwear (but not leather processing), paper (and wood: furniture, forestry, printing), textiles (synthetics, wool and cotton processing, general finishing, carpeting), clothing (a large variety), with the tobacco, chemicals and food industries playing a less important but relevant role. Many of these industries had agricultural materials as input, but other agricultural products per se played a minor role in the GDP of the province. Accommodation, tourism and transport services were advocated as promising areas of employment. However, both the textiles and clothing industries were identified as losers against strong import competition. Employment possibilities were expected to decline. Potential winners were identified as (metals), trade and services, particularly community services (Industrial Development Corporation, 1995). As a result of this information, it seemed that the trade, social services and tourism realms offered suitable potential employment for home economists. However, the general unemployment rate for the province was set at $52 \%$ of the "over 15 year old" age group. In addition, less 
than $5 \%$ of the economically active people were employed in the formal sector. This implied that selfemployment would have to be a major option for graduates.

As KwaZulu-Natal was a predominantly rural province and as many of the dominant industries were agriculturally-based, future students were likely to be rural or newly urbanised. The province would need home economists to facilitate social change and to provide community services for an improved quality of life. This might require a different mode of delivery from the conventional rural extension services. A number of people from development organisations (8) were consequently interviewed at a National Development Society conference in 1991. In addition, three senior staff members in the local municipality were interviewed in connection with staff needs in the development arena. We targeted middle management in development projects, training institutions, local authorities and nongovernmental organisations (NGOs) as potential employers.

One question was, "What did employers expect from their managers of development projects?" The most common responses were "honesty", and "trustworthiness", which when further pursued meant acknowledging and reporting honestly when activities were not occurring as expected, and working responsibly without close supervision. Other responses, not in any specific order of importance, included the following:

- Working independently

- Understanding financial controls

- Communicating well in both oral and written presentations

- Working cooperatively as team members

- Taking responsible initiatives

- Making creative suggestions

- Some computer skills.

These criteria were similar to those mentioned by Bailey et al (1996) who identified seven clusters of transferable skills for professional home economists.

When asked about the value of contextual knowledge, the NGOs reported that their staff needed some knowledge about the development project itself, its processes and progress. These staff should be able to identify the important role players, in both formal institutional systems and in the local community. Many of the projects that were mentioned were predominantly of an incomegenerating, construction (both buildings and infrastructure), or training and community capacity building nature.

An additional environmental factor to be considered was the University of Natal's mission statement which required each graduate to possess certain skills that would have to be incorporated into the curriculum, albeit not necessarily as separate, identifiable courses. These skills included:
- research skills and lifelong learning, working independently and creating knowledge experiences

- critical analysis and problem-solving skills

- basic numeracy and familiarity with information technology

- good writing and presentation skills

- enterprise skills which would sensitise students to small-business and nonformal environments

- the ability to manage projects and direct people.

Additional skills were a keen appreciation of history and the responsibilities of leadership roles in South Africa, and the ability to identify ethical problems and issues (University of Natal, 1994).

The departmental academic staff added more skills related to the organisation and management of real community-based activities, for example making arrangements and appointments, using the telephone, conducting interviews, and extending relevant peripheral knowledge.

\section{PRACTICAL CONSTRAINTS}

There were constraints which circumscribed our activities - and which may well differ between institutions. These constraints were the most difficult to accommodate during the planning stage. Because we were not permitted to introduce a new degree of $B$ Home Economics (because of a government moratorium on new degree names), we adopted the degree structure for a B Social Science (four subjects in each of the first and second year, and two doubleload courses with reduced class contact time in the third year). This materially limited the time available within the degree for home economics content and also demanded substantial optional co-major and supporting subjects. Cross-linking courses from other faculties was not accepted practice, so the possibility of permitting other courses to be offered as part of home economics subject names was not a viable option at the time.

Agriculture had been the home faculty for home economics at this university, but there had been little interaction in the past. Not offering a BSc degree but a degree from another faculty without physically moving presented further obstacles. However, these obstacles were overcome through persuasion.

No additional employment of staff could be expected and staff time was extremely limited (as full teaching and research had to continue at the normal rate). Laboratory courses were expensive and this limited student numbers. These courses were rationalised to permit at least one course that required no laboratory facilities. Students had indicated that they often did not like doing both foods and nutrition or both foods and clothing and would prefer to concentrate more on one subject. This implied that the traditional pairing of subject matter had to be rationalised. 


\section{IDENTIFICATION OF MAJOR THRUSTS}

From extensive discussions conducted with other academics, employers and students, major thrusts for the degree were identified in terms of societal problems to be addressed. These thrusts held implications for course delivery methods and activities as well as for specific content matter. The following thrusts were incorporated into the degree:

- Managerial activity by team members to organise actual events

- Production techniques taught from an entrepreneurial viewpoint

- Analysis and encouragement of social change

- Participative and democratic approaches to course delivery and content

- Greater awareness of the role of societal systems (types and functions) and community issues

- Incorporating student initiatives into courses

- Computer-generated documents to be expected progressively more often

- Gender sensitivity issues in development.

At this stage no specific course content or outlines had been defined. Solely the target employment areas and generic skills requirements had been investigated.

The next stage was to determine the target boundaries for which this information was most needed. Traditionally the home economics course content seemed to be directed at individuals and nuclear families (Eghan, 1990). We felt that this outlook was limited in scope, very microdirected in its ability to encourage social change, and that it would be difficult to encompass both extended and nuclear family functioning in one course. The extended family structure played an influential role in decisions, activities and lifestyles, and could form part of a community or neighbourhood approach. Here, in a democratic society, is where social change could be brought about more effectively (Twelvetrees, 1991) and this focus was selected for the course offerings. This focus would include families and individuals, but in their roles as contributors to community structures. It was acknowledged that because of historic government acts, for example on migrant labour systems, pass laws and natural urbanisation, the roleof the extended family was weakening. Communities might well be expected to assume responsibility for the lost services and the support traditionally provided by the extended family network.

A major underlying reality was the unsuitability of the traditional modes of learning - where knowledge was owned by the lecturers and had to be passed on to the students (Chambers, 1993). Many authors had expressed the sentiment that "the orthodox model on which planning, education, aid and technology development are based, has failed to have any significant impact on alleviating poverty or generating wealth", particularly in the Third World (Hamdi, 1996, citing Dube, 1988; Chambers, 1993). The orthodox model promoted dependency rather than self- sufficiency (especially in relation to technology and general knowledge). Development literature at the time was suggesting the promotion of endogenous development (self-generated progress) through human and institutional relationships. People-driven processes supported the empowerment of communities. The use of indigenous knowledge in formulating programmes to promote self-reliance and human wellbeing had to be encouraged (Hamdi, 1996; Dube, 1988; Chambers, 193). For successful graduates, these were seen as a basis on which to build.

\section{THE STRUCTURE OF THE COURSES FOR THE DEGREE}

The integrated, holistic approach to community issues (as in home economics) was maintained as this was the essence of what differentiated our subject matter from that of other disciplines. The systems approach was the major theoretical premise adopted through all learning materials.

\section{Core content of foci}

Three specific core content foci were identified:

Small-business initiatives These initiatives included income-generation projects, village industries, and small and medium business enterprises. Entrepreneurial risk taking and selfemployment generation had been promulgated by Clem Sunter $(1993 ; 1994)$ as essential to economic empowerment throughout South Africa. Here the traditional home economics subjects of foods, housing and textiles could be included in relation to supplying products for the marketplace. The spectrum could be expanded to include additional topics such as on-farm food processing, traditional crafts, and a greater variety of housing products. All these topics required production skills which could generate incomes for those concerned. General business knowledge such as financial management and marketing had to be included as inherent aspects of all productive activities.

Household food security If there were no foods available in a resource-poor community, it became essential to include the production of food resources as part of the curriculum instead of assuming that all necessary foods were readily accessible. Community gardens, small animal-keeping and farming systems approaches became necessary knowledge. Agricultural product usage, the encouragement of appropriate food processing technology linked to agricultural production, and extending the shelf life of agricultural products were identified as critical aspects of household food security in resource-poor rural areas. Close liaison with agriculture was envisioned but the role of these graduates would be to facilitate the formation of community structures for cooperative enterprises, for example community gardens, poultry projects and 
grinding mills. Knowledge of indigenous foods, appropriate food technology, food product development, marketing and consumer behaviour were appropriately included here. Technical food preparation knowldge remained an essential ingredient.

Development project management Facilitating the formation and functioning of community committees, liaison between professionals and communities, planning of development projects, support for and help with compiling funding requests for projects, and monitoring and evaluating development initiatives were identified as essential elements for community capacity building, particularly in rural and newly urbanised areas. Understanding resource-poor communities, their functioning, cultural aspects of community life, development outcomes and processes were also important. These were appropriate process skills for encouraging development. In order to benefit people's social development and quality of life, there needed to be specific contexts in which community facilitators felt knowledgeable and confident. They, personally, could act as resource people for the communities with which they would interact. The relevant study areas were seen as family studies, social health and nutrition, housing and sanitation.

The literature supported the major foci identified for development in South Africa. These focus areas included entrepreneurship, risk taking and income generation (Sunter, 1993); agricultural development and food processing (Korten, 1990); facilitation of development (Ife, 1995; Chambers, 1993; Twelvetrees, 1991), and general managerial skills (Sunter, 1993). The environment in which these occur, namely communities, then provided the context for food, nutrition, housing and some textiles subject matter. Specific courses were determined within these broad content areas.

Learning activities Simultaneously with planning the content, academic staff members included the required teaching/learning methods to be used, and identified assignments that would expose students to the various outcome skills. Many of the assignments were linked to skills that community development workers, trainers or policy makers would be expected to possess and practise (Ife, 1995; Twelvetrees, 1991; Swanepoel, 1992; Pratt \& Boyden, 1985).

The following are examples of such problem-based assignments or learning activities in the curriculum:

\section{Small-business initiatives}

- Students would be shown how to evaluate their own products, and allocate their own marks in an effort to ensure marketable products. Products would be presented for marking as if for a business customer.
- Students would cost all products and produce a suggested retail selling price, outlet and target market. They would be encouraged to price similar items in shops and to be aware of what would make their products cost-effective.

- Marketing of products would form an integral part of any production-based course. Insight into business feasibility and innovative product ideas would be encouraged.

\section{Household food security}

- The practical component would be maintained with appropriate laboratory and equipment usage. Costing of products and quality control would be integrated into practicals.

- Marketing had to be an integral part of the content. The types of food included foods that were widely used in the diet of the targeted populations in rural KwaZulu-Natal.

- Appropriate technology in processing on-farm products and directed field trips on farming systems for producing food would be included.

- A specialisation would be offered in terms of either food product development or food service management (catering) with appropriate experiential projects.

- Inclusion of indigenous food knowledge, types of foods, cooking methods and availability would be accommodated.

\section{Development project management}

- Visiting speakers involved in development work would be invited to address students on how theories supported practice. Students would be made more aware of the final outcome skills from their studies.

- Suitable social service organisations, development and community-based organisations and their activities would be researched. Library searches, computer and Internet searches, and personal interviews with authorities would be included as assignments. Conducting interviews, using social protocols for making appointments, and using the telephone for official purposes had to be integrated into the formal course activities (thereby including the necessary training).

- Field trips would raise some problems issues. Students would interact with those concerned in order to search with them for possible solutions to such problem issues. The outcome would be a written report based on the findings. Field trips would also provide common experiences for use in lectures and learning activities to contextualise theories, models and other research results. 
- Experiential learning within community developmental organisations through involvement in combined projects would require a written report. The organisation, its procedures, activities and findings would be investigated. Small-group discussions would be arranged for problem-solving situations, with students in the facilitation role - within the community context wherever possible.

- Computer skills would be encouraged through short, computer-generated assignments from the second year of study. Computerised financial management assignments would be taught as an integral part of the curriculum content.

\section{SELECTING THE NAME}

Lastly, through wide-ranging discussions with people working in the development arena, we selected the course names and a departmental name that would reflect the new emphases of the curriculum. After a debate on names already used for "Home Economics", both overseas and locally, for example Human Ecology, Community Development, New Home Economics, Consumer Studies, the choice was narrowed down to Resource Management. Identifying the focus and limits of this generic name was more difficult. The name "Community Resources" reflected the general ethos of the subjects while the individual subjects were named Community Resource Production, Community Resource Development and Community Resource Management. All of these were to be offered as majors.

Community Resource Production reflected smallbusiness initiatives in clothing, textile and craft production, and Community Resource Development concentrated on developing resources for improved household food security and related food processing technology. Community Resource Management focused on the management of development projects and on building community capacity within the specific contexts of improving nutrition, health and housing in developing communities.

The curriculum for the degree thus included a selection of subjects with students permitted the option of taking one, two or all three of the Community Resources subjects. A preferred degree curriculum was presented and time-tabled, which ensured that students could co-major with Sociology, Psychology, Geography and Zulu, with additional minors of Legal Studies, English or Applied Language Studies, Economics and Religious Studies. The degree required three years of study and could be followed by a B Social Science Honours, or a Postgraduate Diploma in Marketing, Human Resource Management, Adult Education, Tertiary Education, Development Studies, Applied Social Science or Community Development for those desiring greater specialisation. A Higher Education Diploma was available to students who wished to teach in high schools and who had taken all three Community Resources subjects (with an additional teaching subject to second-year level).

\section{MARKETING THE CHANGES}

This is an aspect of the curriculum revision which, with hindsight, was not conducted satisfactorily. Because of insufficient consultation within the University community during the curriculum development process, extensive presentations were required - to the staff in student admissions, student counselling, research units in related fields, and other academics within the faculty itself. In addition, extensive marketing was undertaken for potential students and employers. This task was additionally onerous in that both the NGO field of employment and the origins of students to this University were changing rapidly.

Many academics were unaware that the changes encompassed more than a superficial name change. We would suggest a wider consultation route, coopting any interested academic and research member in the university community, before and during the curriculum design process. A curriculum committee comprising employers and graduates would be useful for periodic updating of the curriculum in the future.

Another aspect of the paradigm shift and the resultant reconceptualisation which was in some aspects less successful, was the reorientation of staff in regard to their curriculum offerings. The academic staff members who had been intimately involved in the changes were able to effect the paradigm shift in both content and method of delivery. In spite of real enthusiasm for the changes, those academics who were not part of the ongoing process but who were drawn in periodically for reports and for specific response opportunities found the paradigm shift difficult to translate into course material.

With hindsight, the process should have continued to motivate and train staff after the introduction of the new subjects. Problem-based learning, participatory curriculum activities, democratic teaching methods, reading material searches and writing new course materials should have been actively supported as part of the teaching. More specific training should have been provided for all.

\section{CONCLUSION}

The following are major insights from the reconceptualisation of Home Economics:

In conventional Home Economics the underlying assumption was that there were resources and raw 
materials available with which to manage or produce. This led to the perception that Home Economics was a subject for middle-class people. In resource-poor communities, however, the emphasis had to move to resource creation and appropriate usage.

The curriculum design process should be outcomesbased - with involvement of both employers and graduates in the process. The stages suggested by Tyler and Levine are worth following. Educational needs have to be assessed first, and outcomes (objectives in terms of skills and abilities) have to be determined. The focus of the total curriculum should be kept paramount for all subject matter. Delivery methods, assignments, course content and experiential training should be subjected to relevancy tests before they are included. Continuous evaluation is required with periodic revision of both outcomes and learning activities. Continued support is required after the introduction of new courses to ensure that the change is carried through by all the stakeholder. Suitable textbooks and class materials should support the process which may demand local authorship.

Delivery methods should be more participatory and problem-based. Techniques per se cannot be taught, but have to be placed within a relevant context where the knowledge is to be synthesised and used. Applying facts in other contexts is not automatic but must be practised.

The success of the new curriculum and ethos of Community Resources also lies in feedback from employers and working graduates. Many of these graduates are working in fields related to development - land rights restitution organisation, video production on development topics, employee affairs in a personnel department, Home Economics teachers, a nutritionist in a health department - 83\% of the first class (and the remaining students are still studying). Subsequent graduates tended to register for further study. One graduate is employed in community capacity building, another is a researcher with development consultants, and no information is available about the remaining two graduates.

In view of the major reconceptualisation of Home Economics throughout Africa, this process that resulted in a successful paradigm shift may well illustrate a model of success for others to follow.

\section{REFERENCES}

BAILEY, S, KITSON, M \& MARLOW, N (1996):
Development of transferable skills to meet the needs of United Kingdom and Dutch employers, in Research Abstracts of IFHE World Congress, Bangkok.

BOUD, D \& FELETTI, G (1991): The challenge of problembased learning. London. Cogan Page.

CHAMBERS, R (1993): Challenging the professions: frontiers for rural development. London. Intermediate Technology.

DOLL, RC (1989): Curriculum improvement. London. Allyn \& Bacon.

DUBE, SC (1988): Modernisation and development: the search for alternative paradigms. London. Zed.

EGHAN, F (1990): Reconceptualising Home Economics programs in West Africa for the $21^{\text {st }}$ century, in Williams, SK, West, DL \& Murray, EC. Looking towards the $21^{\text {st }}$ century: Home Economics and the global community. Mission Hills. Glencoe/McGraw-Hill.

GREYVENSTEIN, L (1994): The year of the family: refocusing on the family though changing perspectives. J Dietet Home Econ 22(2): 104-107.

HAMDI, N (1996): Educating for real: the training of professionals for development practice. London. Intermediate Technology.

IFE, J (1995): Community development: creating community alternatives - vision, analysis and practice. Melbourne. Longmans.

INDUSTRIAL DEVELOPMENT CORPORATION (IDC) (1995): KwaZulu-Natal Industrial Profile and Current National Initiatives. Presentation to the Policy Drafting Secretariat of the KwaZulu-Natal Regional Economic Forum. KORTEN, DC (1990): Getting to the $21^{\text {st }}$ century. West Hartford, Connecticut. Kumarian.

KWAWU, J (1993): A proposal for reorienting the Home Economics profession and programmes in sub-Saharan Africa, in Williams, SK, West, DL \& Murray, EC. Looking towards the $21^{\text {st }}$ century: Home Economics and the global community. Mission Hills. Glencoe/McGraw Hill.

LEVINE, A (1978): Handbook on undergraduate curriculum: a report for the Carnegie Council on Policy Studies in Higher Education. Washington. Jossey-Bass.

MURRAY, E (1993): Reconceptualising Home Economics instruction and research programs with particular reference to developing countries: a model and a process, in Murray, E (1993), Reorienting Home Economics in Africa. Nairobi. HEAA

PRATT, B \& BOYDEN, J (1985): The field directors' handbook: an Oxfam manual for development workers. Oxford. Oxfam.

SUNTER, C (1994): The casino model. Cape Town. Human \& Rousseau.

SUNTER, C (1993): Pretoria will provide and other myths. Cape Town. Human \& Rousseau.

SWANEPOEL, H (1992): Community development: putting plans into action. Kenwyn. Juta.

TWELVETREES, A (1991): Community work. London. MacMillan.

UNIVERSITY OF NATAL (1994): Vice-Chancellor's review: 